\title{
Microstructure of microphytobenthic biofilm and its spatio-temporal dynamics in an intertidal mudflat (Aiguillon Bay, France)
}

\author{
O. Herlory ${ }^{1,2, *}$, J.-M. Guarini ${ }^{2}$, P. Richard ${ }^{2}$, G. F. Blanchard ${ }^{1}$ \\ ${ }^{1}$ Laboratoire de Biologie et Environnement Marins (LBEM), FRE 2727, CNRS-Université de La Rochelle, \\ Avenue Michel Crépeau, 17042 La Rochelle, France \\ ${ }^{2}$ Centre de Recherche sur les Ecosystèmes Marins et Aquacoles (CREMA), UMR 10, CNRS-IFREMER, BP5, \\ 17137 L'Houmeau, France
}

\begin{abstract}
The spatio-temporal dynamics of the microphytobenthic biofilm was analysed at microscale over a complete day-time emersion period in an intertidal mudflat. The structures of the biofilm were monitored by analysing the variability of the epipelic diatom cover in the horizontal dimension and the kinetics of biomass dispersion in the vertical dimension. Colonisation of the sediment surface by diatoms was rapid (within $15 \mathrm{~min}$ ); $75 \%$ of the biomass contained in the top $1 \mathrm{~mm}$ was concentrated in the upper $200 \mu \mathrm{m}$, but the cover never reached $100 \%$. This biomass had a higher chlorophyll a/pheopigment ratio than deeper in the sediment, suggesting a better physiological state and a higher photosynthetic potential. The dynamics of the biomass in the upper $200 \mu \mathrm{m}$ turned out to be independent of that deeper in the sediment, supporting the concept of an independent surface compartment, mainly responsible for primary production. In the second part of emersion, the horizontal dispersion of the microphytobenthic biofilm was concomitant with the onset of downward migration. The process was slow, showing that the diatoms were not phased in their downward movement. The migration process appeared to be asymmetrical: rapid upward migration and biofilm formation versus slow downward movement and dispersion of the biofilm. To take into account these structural characteristics of the biofilm and to simulate its dynamics, we developed a new mathematical model that provides simulations consistent with our observations. We have also shown for the first time that the constitution of the biofilm at the sediment surface (0 to $200 \mu \mathrm{m})$ is connected to an increase of biomass in the top $1 \mathrm{~cm}$.
\end{abstract}

KEY WORDS: Microphytobenthos - Biofilm - Intertidal mudflat - Spatio-temporal dynamics · Microscale Resale or republication not permitted without written consent of the publisher

\section{INTRODUCTION}

Intertidal mudflats are highly productive ecosystems associated to estuaries and semi-enclosed bays. In western Europe, these geomorphological structures are mostly devoid of macrophytes, but nevertheless exhibit a high primary productivity due to the presence of microphytobenthos (MacIntyre et al. 1996, Underwood \& Kromkamp 1999). The benthic microalgae are mainly composed of diatoms, either closely attached to sand grains (epipsammon) or free and motile in fine muds (epipelon) (Round 1971). The fre- quent dominance of epipelic diatoms at the surface of mudflats gives rise to an efficient primary production system (Guarini et al. 2000b), in which diatoms migrate vertically in the surface sediments during diurnal emersions, according to an endogenous rhythm (Palmer \& Round 1967, Serôdio et al. 1997), to form a temporary biogenic structure assumed to be mainly responsible for primary production (Serôdio et al. 1997, Serôdio \& Catarino 2000, Defew et al. 2002). In particular, the formation of the biofilm and its photosynthetic activity is believed to cause the increase of microphytobenthic biomass during diurnal emersions (Blan- 
chard et al. 1998, 2001, 2002), but the relationship has never been demonstrated. Moreover, as these epipelic microalgae also produce extracellular polymeric substances (EPS) - due to their motility (Edgar \& Pickett-Heaps 1984, Smith \& Underwood 1998, Decho 2000) and their metabolism (Smith \& Underwood 2000, De Brouwer \& Stal 2001, Perkins et al. 2001) - the 'microphytobenthic biofilm' is thought to play a key role in sediment biostabilisation (Paterson 1989, Underwood \& Paterson 1993, Paterson et al. 2000, Yallop et al. 2000, Orvain et al. 2003). The biofilm concept is therefore central to our current understanding of the primary production system and of the overall functioning of intertidal mudflats.

The surficial and transient structure of the microphytobenthos has been well identified and visualised by microscopic observations at the scale of individual cells (Gouleau 1976, Paterson 1986, 1995, Paterson et al. 1986), by vertical profiles of microalgal biomass at very small vertical scales (Paterson et al. 2000, De Brouwer \& Stal 2001, Kelly et al. 2001), or by non-destructive measurements based on in situ and in vivo fluorescence signals (PAM fluorometry) at the sediment - air interface (Serôdio et al. 1997, Serôdio \& Catarino 2000, Perkins et al. 2001). However, all these qualitative and quantitative observations aimed at providing an average representation of the biofilm, which has thus far been best conceptualised and modelled as a continuous layer of a few cells at the surface of the mud, characterised by synchronous vertical movements at the beginning and the end of diurnal emersions (Guarini et al. 2000b).

Such an idealised representation, although easily operational for modelling purposes (Guarini et al. 1999, 2000a), does not take into account the full complexity of the biofilm structure and dynamics. Obviously, a full statistical description of the biofilm, with its horizontal, vertical and temporal dimensions, is lacking, thus making it critical to extrapolate our current knowledge at the scale of the whole mudflat. In particular, there is no information about the horizontal spatial distribution at microscale or the dynamic relationship between the horizontal and vertical dimensions of the biofilm.

Therefore, to bring new insights into these important issues, the present field study was undertaken. The horizontal structure of the biofilm at the sediment-air interface and the vertical profile of the biomass at a millimetre and micrometre scale were monitored over the course of a diurnal emersion period. In parallel, the increase of biomass during emersion was tested on an independent sample, to establish a direct link between the constitution of the biofilm at the air-sediment interface and the short-term dynamics of the total photosynthetically active biomass (top $1 \mathrm{~cm}$ of the sediment; see Guarini et al. 2000a). Finally, based on these measurements, an attempt was made to revise our conceptual view of the microphytobenthic biofilm and to propose a mathematical model that accounts for its spatio-temporal dynamics.

\section{MATERIALS AND METHODS}

Study site and sampling. The study was undertaken in Aiguillon Bay which is located along the French Atlantic coast $\left(47^{\circ} 00^{\prime} \mathrm{N}, 1^{\circ} 05^{\prime} \mathrm{W}\right)$. It is dominated by bare intertidal mudflats composed of very fine muds. Sampling was carried out on 25 July 2003, during spring tide conditions, when diurnal emersion periods occurred at midday and lasted about $4 \mathrm{~h}$.

A first series of sediment samples was collected within a quadrat of about $1 \mathrm{~m}^{2}$ for the description of the spatio-temporal dynamics of the microphytobenthic biofilm during a full emersion period. Fifteen $5 \mathrm{~cm}$ diameter cores were taken within this quadrat at each of the following times: at the beginning of emersion ( $t=0 \mathrm{~min})$, at $t=15 \mathrm{~min}$, at $t=45 \mathrm{~min}$, at mid-exposure ( $t=2 \mathrm{~h} 15 \mathrm{~min}$ ), at $t=3 \mathrm{~h} 15 \mathrm{~min}$ and at the end of emersion just before the flooding tide $(t=4 \mathrm{~h} 15 \mathrm{~min})$. For each core, the sediment was frozen with liquid nitrogen so as not to disturb the sediment surface with its microalgal assemblage. The sediment was frozen over the top $1 \mathrm{~cm}$. Cores were stored in the dark at $-20^{\circ} \mathrm{C}$ until further processing. The surface area of each core was observed using scanning electron microscopy (SEM), and subsamples were isolated for millimetric and micrometric vertical profiling of chlorophyll $a$ (chl $a$, proxy for microalgal biomass).

A second series of sediment cores was collected within a neighbouring quadrat (about $1 \mathrm{~m}^{2}$ ) to test for the increase of biomass during the diurnal emersion. Five $15 \mathrm{~cm}$ diameter cores were taken at the beginning and at the end of the emersion period, according to the appropriate sampling technique reported in Blanchard et al. (2002). The top $1 \mathrm{~cm}$ of cores was cut off, then freeze-dried before measurement of the chl a concentration.

Scanning electron microscopy. Uncoated sediment samples were placed in the microscope chamber (JEOL 5410 LV, CCA University of La Rochelle), where the surface sample was gently sublimed off by vacuum. Samples were not coated with gold because chl a was measured on the same samples. The sediment surface was examined at a high acceleration voltage $(20 \mathrm{kV})$. For each examined core, 3 pictures were randomly taken. On each of these pictures, the surface area covered with diatoms, relative to the total surface area of the picture, was manually out- 
lined and quantified with image analysis software (Biocom Visiolab).

Quantification of biomass vertical profiles. Samples observed by SEM were freeze-dried before pigment analyses. For each core, 3 blocks were cut up $(8 \times 8 \mathrm{~mm}, 1.5 \mathrm{~cm}$ height $)$, then placed in a microtome and sectioned at a millimetre scale down to $5 \mathrm{~mm}$. Another series of 3 blocks was isolated to section the top $1 \mathrm{~mm}$ into $200 \mu \mathrm{m}$ slices. For each slice (millimetre or micrometre), pigments were extracted in $90 \%$ acetone in the dark overnight at $5^{\circ} \mathrm{C}$ and then $\mathrm{chl} a$ and pheopigment were detected fluorometrically and quantified using Lorenzen's (1966) equations. Results

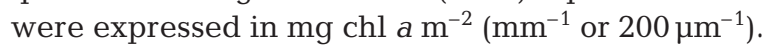

Statistical analyses. The variance to mean ratio was calculated first to characterise the horizontal spatial distribution of the cover rate at the surface of the sediment. Departure from a random distribution was tested using a Chi-squared test for agreement with a Poisson series (Elliott 1977).

To test for the vertical stratification of the biomass due to migration, the existing covariance of the data in space and time makes classical statistical inference methods like analyses of variance unusable. Therefore, randomisation tests were designed (Kempthorne 1955, Manly 1997). These tests are based on the calculation of the distance between the data distribution and a complete random distribution. A vertical pattern can be found in the distribution of the biomass, $b$, among $Q$ levels. The procedure tests the null hypothesis $H_{0}: \bar{b}_{1}=\ldots=\bar{b}_{q}=\ldots=\bar{b}_{Q}$ (the mean biomass is the same in every vertical level), with the alternative hypothesis, $H_{1}$, assuming that at least one of the mean values, $\bar{b}_{q}$, is different from the other ones. The following statistic, $f$, was used:

$$
f=\frac{\left(\mathrm{RS}_{0}-\mathrm{RS}_{1}\right) /\left(\mathrm{v}_{0}-\mathrm{v}_{1}\right)}{\mathrm{RS}_{1} / \mathrm{v}_{1}}
$$

where

$$
\left\{\begin{array}{l}
\mathrm{RS}_{0}=\sum_{i=1}^{N}\left(b_{i}-\bar{b}\right)^{2} \\
\mathrm{RS}_{1}=\sum_{q=1}^{Q} \sum_{j=1}^{J_{q}}\left(b_{j}-\bar{b}_{q}\right)^{2}
\end{array}\right.
$$

with $J_{q}$ the number of biomass values by level $q$ and $v_{0}=N-1$ and $v_{1}=N-Q$.

The observed statistical values $f_{\text {obs }}$ (calculated each time from $N$ observations) were compared to the empirical distributions of $f$, which were computed by performing 1000 times $N$ random permutations in the data set. The empirical distribution is called the randomisation distribution of the data set. The total number of random permutations that can be performed is $N$ !; this number was $>1000$. The probability $\operatorname{Proba}\left(f>f_{\text {obs }} \mid H_{0}\right)$ represents the first type error, to reject $H_{0}$ when $H_{0}$ is true. A threshold of $5 \%$ was used to decide whether or not $H_{0}$ can be rejected.

\section{RESULTS}

Quantitative analysis of the dynamics of the horizontal structure of the biofilm during emersion

At the beginning of diurnal emersion, the sediment surface was already partially covered with diatoms (Fig. 1A). Microalgae coated about 25\% (14 to 36\%, $95 \%$ confidence limits) of the sediment surface (Fig. 2), because the upward migration process is fast and, for practical reasons, the sampling only occurred a few minutes after the tide receded. Moreover, the frequency distribution of the cover at that time (Fig. 2A) clearly points out that there was a great deal of variability since almost $45 \%$ of the observations had a cover in the range 0 to $10 \%$, while $<20 \%$ of the observations had a cover $>50 \%$. The frequency distribution is skewed to the right and does not follow a Poisson distribution, with a variance significantly higher than the mean $(\mathrm{p}<0.05)$; the horizontal distribution of the cover was contagious, thus indicating that diatoms were distributed in patches at the sediment surface.

After only $15 \mathrm{~min}$ of exposure, the cover was close to $80 \%$ (71 to $86 \%, 95 \%$ CL), with almost all observations being $>50 \%$ of the cover (Figs. 1B \& 2B). The frequency distribution is skewed to the left and is contagious ( $p<0.05$ ). At $45 \mathrm{~min}$ of exposure, the situation was very similar (Figs. $1 \mathrm{C} \& 2 \mathrm{C}$ ). In the middle of emersion ( $2 \mathrm{~h} 15 \mathrm{~min}$ ), the average cover was about $90 \%$ (84 to $94 \%, 95 \%$ CL) (Figs. 1D \& 2), with $>60 \%$ of the observations being $>90 \%$ of the cover (Fig. 2D). At that time the variability in cover was low, and the frequency distribution of the cover did not differ from a Poisson distribution ( $p>0.05)$. Therefore, the biofilm covered between 80 and $90 \%$ of the surface sediment for the first half of emersion, after a rapid upward migration of microalgae and a change from a contagious to a random distribution of the cover.

In the second part of the emersion period, we observed (after $3 \mathrm{~h} 15 \mathrm{~min}$ of exposure) that the downward migration had already begun, with a decrease of the average cover (down to about 65\% with 49 to $82 \%, 95 \%$ CL) (Figs. 1E \& 2) and an obvious dispersion of the biofilm as evidenced by the very scattered frequency distribution of the cover (Fig. 2E): the frequency distribution does not follow a Poisson distribution, the variance being significantly higher than the mean $(\mathrm{p}<0.05)$. This downward migration did not start at the same time everywhere in the observed area: about $13 \%$ of the observations 

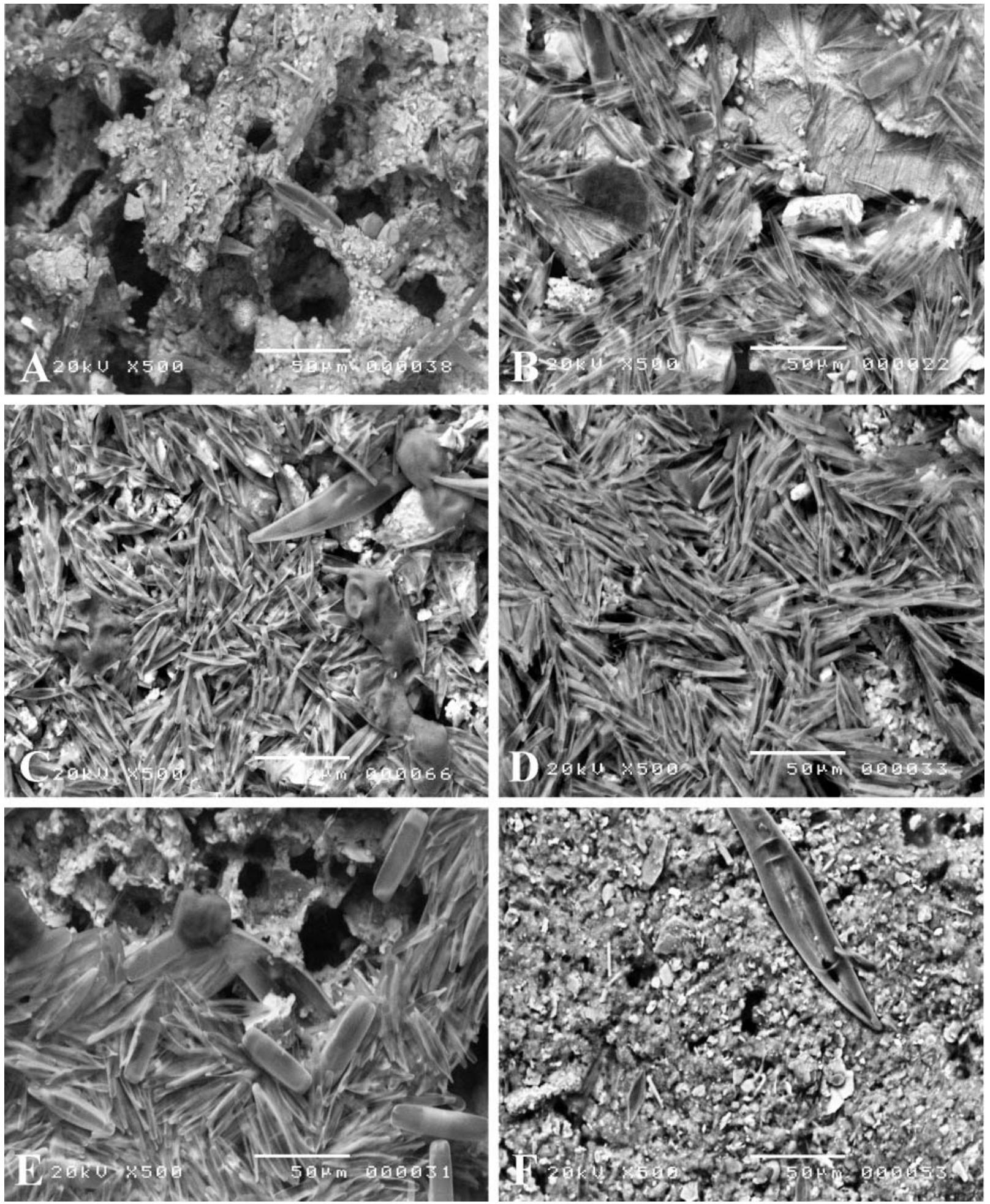

Fig. 1. Scanning electron microscopy pictures of sediment surface (scale bars: $50 \mu \mathrm{m}$ ): (A) at the beginning of the emersion period, only a few diatoms were present at the sediment surface; diatom cover was $24 \%$; (B) 15 min later, more diatoms were present at the sediment surface, covering up to $78 \%$; (C) 30 min later $(t=45 \mathrm{~min})$, diatom cover was still $78 \%$; (D) at mid-exposure $(t=2 \mathrm{~h} 15 \mathrm{~min})$, microphytobenthos coated $89 \%$ of the sediment surface; (E) $1 \mathrm{~h}$ before immersion $(t=3 \mathrm{~h} 15 \mathrm{~min})$, diatom cover was down to $66 \%$; $(\mathrm{F})$ at the end of exposure ( $t=4 \mathrm{~h} 15 \mathrm{~min})$, diatoms were still present at the sediment surface, but covered only $8 \%$ of the surface 


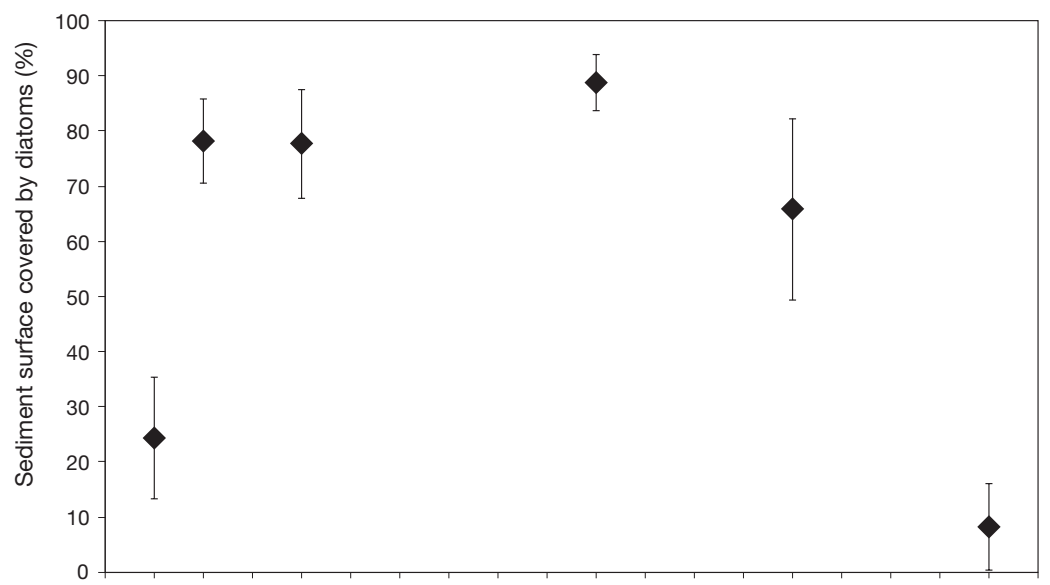

0:00 0:15 0:30 0:45 1:00 1:15 1:30 1:45 2:00 2:15 2:30 2:45 3:00 3:15 3:30 3:45 4:00 4:15 4:30 Relative emersion time (hour:minute)
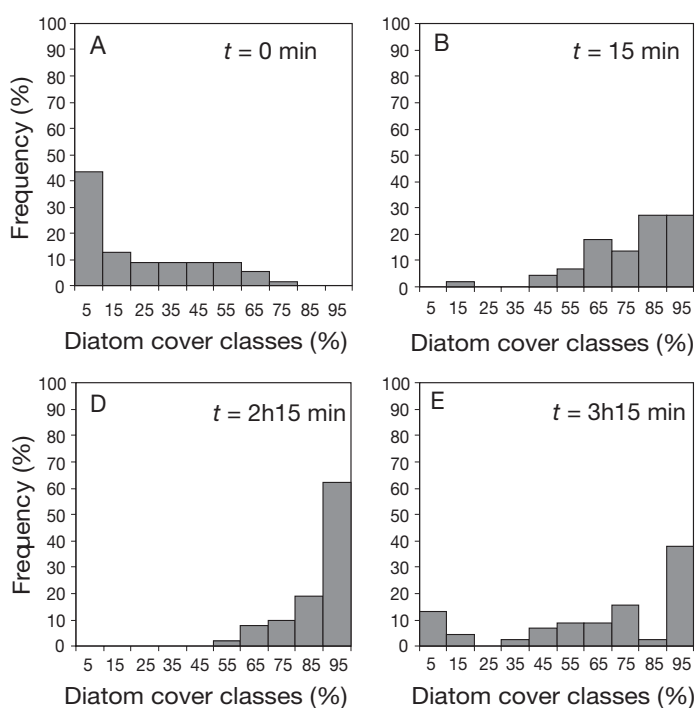

Fig. 2. Averaged percentages of sediment covered by diatoms with confidence limits at $95 \%$ versus the relative emersion time. Each mean percentage is shown in detail by a frequency distribution of cover rates $(\mathrm{A}-\mathrm{F})$

showed almost no diatoms at the sediment surface, while about $38 \%$ of the observations showed a sediment surface almost full of cells (Fig. 2E). At the very end of exposure (4 h $15 \mathrm{~min}$ ), the downward migration was almost over (Fig. 2F), with an average cover of $<10 \%(0.5$ to $16 \%, 95 \% \mathrm{CL})$. The frequency distribution was contagious ( $p<0.05)$, with the remaining diatoms being patchily distributed at the sediment surface.

As a whole (Fig. 2), it is clear in this particular case that the process of vertical migration was asymmetrical, the upward movement being faster than the downward migration (i.e. steeper slope of cover change at the beginning of emersion).

\section{Qualitative analysis of the vertical structure of the diatom biofilm during emersion}

SEM pictures show the aspect of the sediment-air interface when the biofilm was not present at the beginning and at the end of the emersion period (Fig. 3A,F). On the contrary, Fig. 3B-E show the structure of the biofilm when diatoms accumulated on top of the sediment during emersion. In the latter case, the biofilm is composed by a few cell layers, and its thickness ranged between 50 and $100 \mu \mathrm{m}$. In some places, tufts of diatoms, oriented vertically, formed a much thicker biofilm. As a whole, it clearly turns out that the biofilm is a well-defined structure on top of the sediment surface, with only very few algal cells underneath in the photic zone of the sediment, which is very narrow in such fine muds (a few hundred $\mu \mathrm{m})$.

\section{Quantitative analysis of the vertical profiles of biomass}

At a millimetre scale over the upper $5 \mathrm{~mm}$ (Fig. 4), it is clear that biomass was concentrated in the top $1 \mathrm{~mm}$ during emersion (randomisation test, $\mathrm{p}<0.05$; about $40 \%$ on average over the whole emersion period). In addition, the biomass in the top $1 \mathrm{~mm}$ at mid-exposure was higher than at the beginning and at the end of emersion (test of differences, $\mathrm{p}<0.05$ ).

By focusing at the sediment-air interface (the top $1 \mathrm{~mm}$ only) with a higher spatial (every $200 \mu \mathrm{m}$ ) and temporal resolution (the same as for horizontal dynamics) (Fig. 5), it turned out that biomass was actually concentrated in the top $200 \mu \mathrm{m}$ (randomisation test, $\mathrm{p}<0.05)$. In addition, during the upward migration of microalgae, biomass significantly (test of differences, $\mathrm{p}<0.05$ ) and rapidly increased from about 7 (5 to $9 \mathrm{~g} \mathrm{chl} \mathrm{a} \mathrm{m}^{-2}, 95 \% \mathrm{CL}$ ) to about $17 \mathrm{mg} \mathrm{chl} \mathrm{a} \mathrm{m}{ }^{-2}$ (13 to $21 \mathrm{mg} \mathrm{chl} \mathrm{a} \mathrm{m}{ }^{-2}, 95 \%$ CL) in the upper $200 \mu \mathrm{m}$, $15 \mathrm{~min}$ after exposure. At mid-exposure (2 h $15 \mathrm{~min})$,

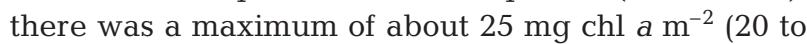

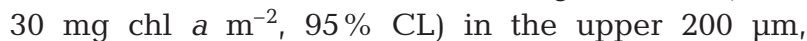
corresponding to about $75 \%$ of the biomass contained in the top $1 \mathrm{~mm}$. During the second half of emersion, when downward migration took place, there was a progressive decrease of biomass in the top $1 \mathrm{~mm}$, with a lower proportion in the $200 \mu \mathrm{m}$ surficial layer (down to $40 \%$ ) and more biomass (about $60 \%$ ) in the intermediate levels (200 to $1000 \mu \mathrm{m}$ ). 

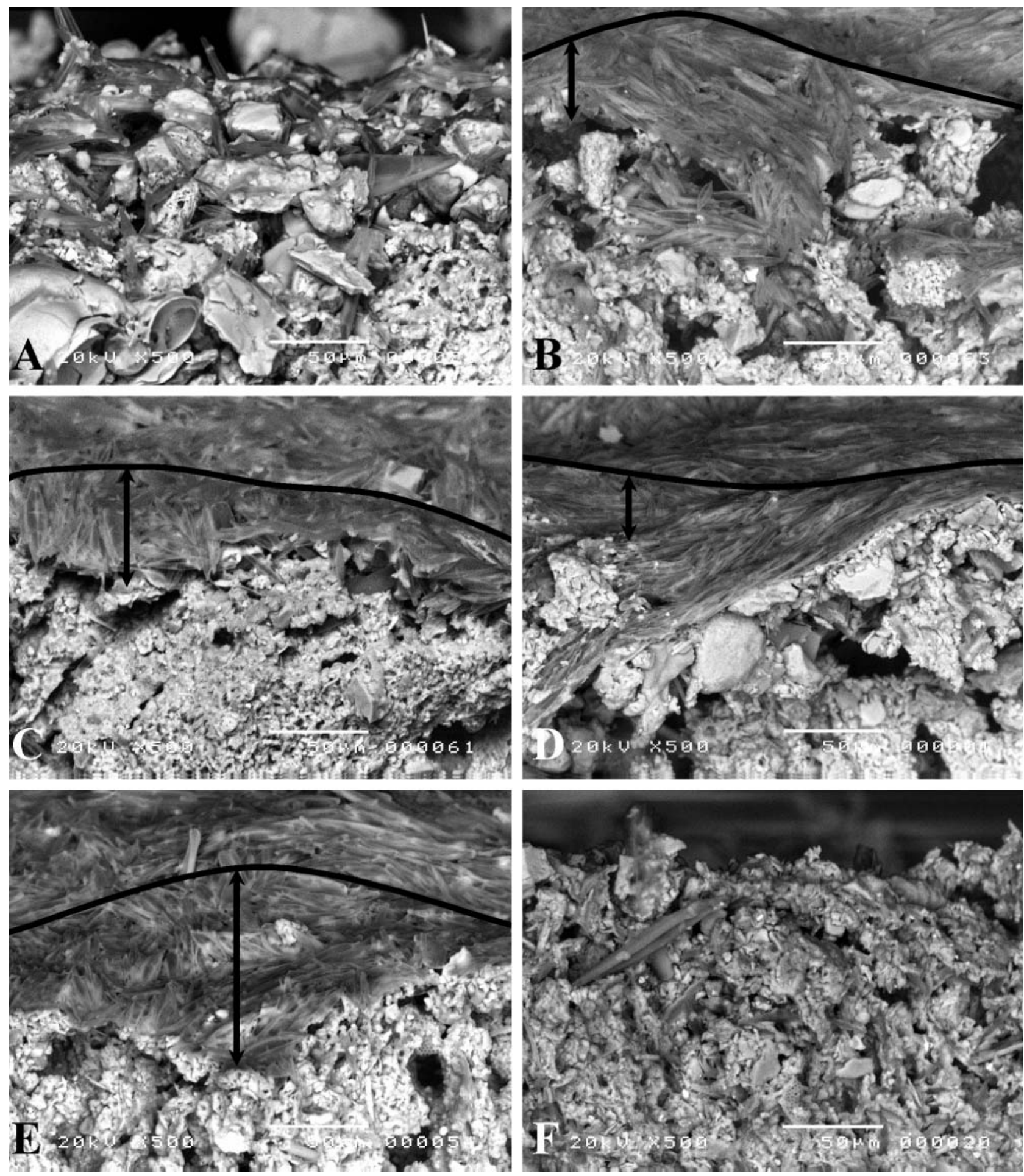

Fig. 3. Vertical distribution of microalgae (scanning electron microscopy, scale bars: $50 \mu \mathrm{m}$ ) (black lines indicate the top of biofilm): (A) beginning of emersion $(t=0 \mathrm{~min})$, microalgae were scattered in the sediment; (B) 15 min of exposure, diatoms were concentrated at the surface to form a ca. $50 \mu \mathrm{m}$ thick biofilm composed of a few cell layers; note also the presence of a patch of diatoms; (C) $45 \mathrm{~min}$ of exposure, another view of the biofilm; (D) at mid-tide ( $t=2 \mathrm{~h} 15 \mathrm{~min}$ ), presence of a patch of diatoms under the biofilm as in panel $\mathrm{B}_{i}(\mathrm{E}) 1 \mathrm{~h}$ before immersion $(t=3 \mathrm{~h} 15 \mathrm{~min})$, pack of diatoms of about $100 \mu \mathrm{m}_{i}(\mathrm{~F})$ end of emersion $(t=4 \mathrm{~h} 15 \mathrm{~min})$, no biofilm on the top of sediment; diatoms were scattered in the sediment 
A

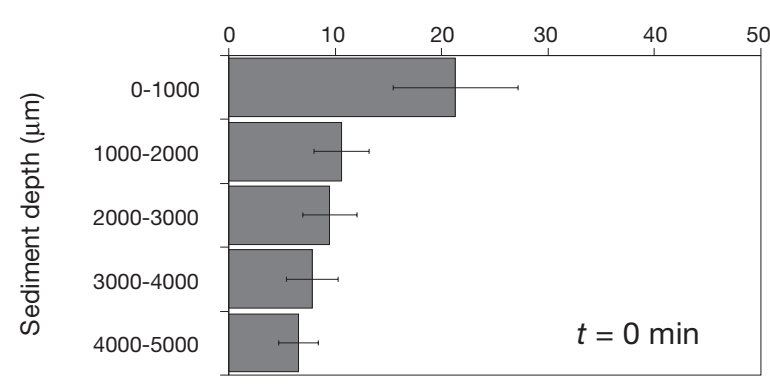

B

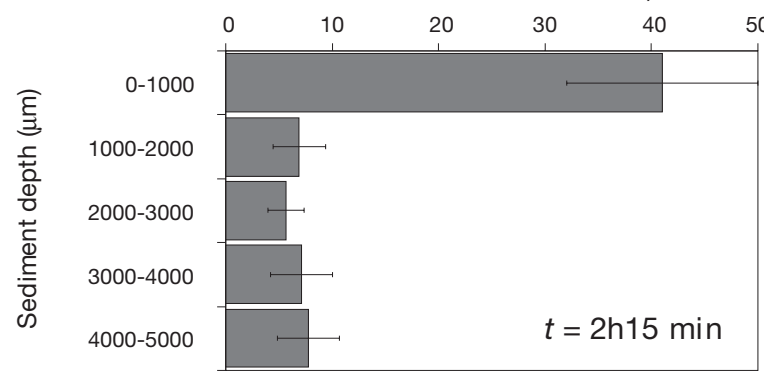

C

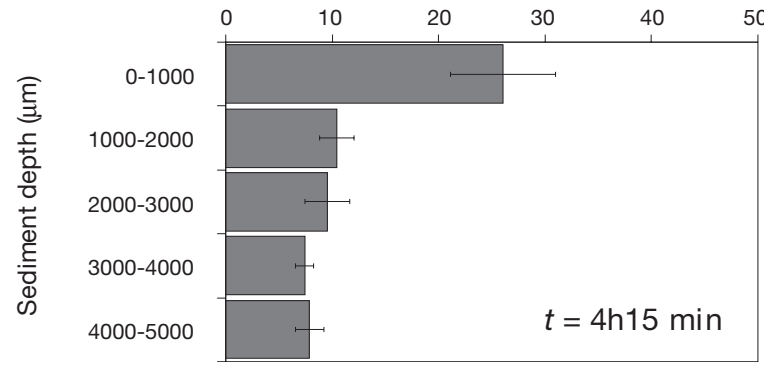

Fig. 4. Vertical profile of biomass at a millimetre scale over the upper $5 \mathrm{~mm}$. Horizontal bars represent mean chl a concentrations $(\mathrm{n}=15)$, with confidence limits at $95 \%$. Profiles were established at 3 times over the emersion period: (A) at the beginning ( $t=0 \mathrm{~min})$, (B) at mid-exposure $(t=2 \mathrm{~h} 15 \mathrm{~min})$ and

(C) at the end of the emersion period ( $t=4 \mathrm{~h} 15 \mathrm{~min})$

The chl $a$ to pheopigment (chl a/pheo) ratio gives a rough indication of the physiological state of microalgae, a high ratio being indicative of a higher potential for photosynthetic activity. The vertical profile within the top $1 \mathrm{~mm}$ clearly shows that the $\mathrm{chl}$ a/pheo ratio is much higher in the top $200 \mu \mathrm{m}$ at each sampling time of emersion period (about $4 ;$ Fig. 6 ). If we take into account the duration of exposure, it turns out that there was a consistent pattern of change in the ratio during emersion: in the intermediate levels (200 to $1000 \mu \mathrm{m}$ ), the ratio appears to be lower in the middle of emersion than at the beginning and at the end, that is, after downward migration and before upward migration; this was not the case at the surface or deeper in the sediment $(<1 \mathrm{~mm})$.

\section{Biomass increase during diurnal emersion}

Biomass measurements in the top $1 \mathrm{~cm}$ clearly show that there was a significant increase of biomass (paired $t$-test, $\mathrm{p}<0.05$ ) between the beginning (74.5 mg chl a m${ }^{-2}$ with 62.7 to $86.3 \mathrm{mg}$ chl a m${ }^{-2}$, $95 \% \mathrm{CL})$ and the end $\left(95.9 \mathrm{mg}\right.$ chl a m${ }^{-2}$ with 82.5 to $109.3 \mathrm{mg} \mathrm{chl} \mathrm{a} \mathrm{m}{ }^{-2}, 95 \% \mathrm{CL}$ ) of diurnal emersion; the net increase of biomass was $29 \%$. Biomass measurements in another quadrat (with larger cores of $15 \mathrm{~cm}$ diameter) show the same trend: biomass increased significantly (paired $t$-test, $\mathrm{p}<0.05$ ) from

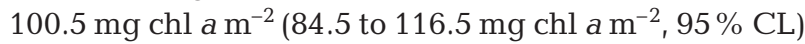
to $128.2 \mathrm{mg} \mathrm{chl} \mathrm{a} \mathrm{m}^{-2}$ (114.1 to $142.1 \mathrm{mg} \mathrm{chl} \mathrm{a} \mathrm{m}^{-2}$, $95 \%$ $\mathrm{CL}$ ) during emersion, that is a $28 \%$ net increase.

\section{DISCUSSION}

Although previous investigations have described the microphytobenthos biofilm (Paterson 1986, 1989, 1995, Paterson et al. 1986) and some aspects of its dynamics (Serôdio et al. 1997, Yallop et al. 2000, De Brouwer \& Stal 2001, Kelly et al. 2001, Perkins et al. 2001), the present study aimed to characterise its microstructure and its spatio-temporal dynamics, using different descriptors simultaneously. Our results all converge to reveal quantitatively the existence of this biogenic structure at the sediment surface and its direct functional relationship with the temporal dynamics of the whole biomass on mudflats. Our detailed analysis at the microscale level allows us to bring out structural and functional characteristics which have thus far been overlooked and which have fundamental implications for the assessment of primary production at the scale of the whole mudflat.

\section{Microstructure of the biofilm and its dynamics}

The kinetics of the cover rate by the biofilm (Fig. 2) was consistent with the amount of biomass in the top $200 \mu \mathrm{m}$ (Fig. 5) and the formation/dispersion of a dense cell layer at the sediment surface (Figs. 1 \& 3). During the upward migration process, the cover rate rapidly increased to reach a maximum value of 80 to $90 \%$ dur-

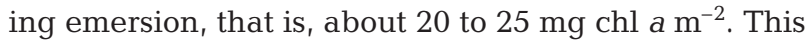
accumulated biomass at the surface has 2 very important characteristics: (1) the chl a/pheo ratio is much higher at the sediment-air interface (Fig. 6; about twice as high in the top layer as in the immediate underlying sediment), indicating a better physiological state through the photosynthetic activity; (2) the biomass in the surface layer ( 0 to $200 \mu \mathrm{m}$ ) appears to have its own dynamics compared to the deeper sedi- 
A

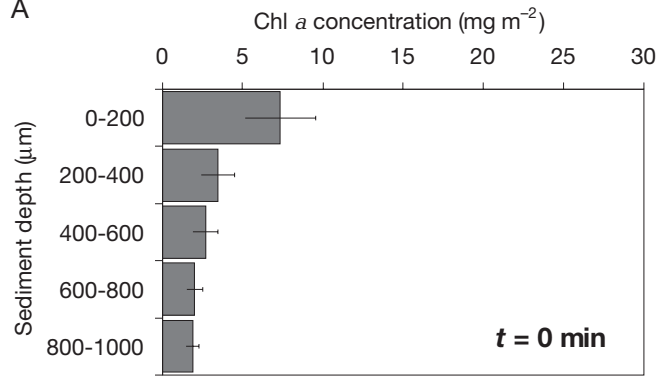

C

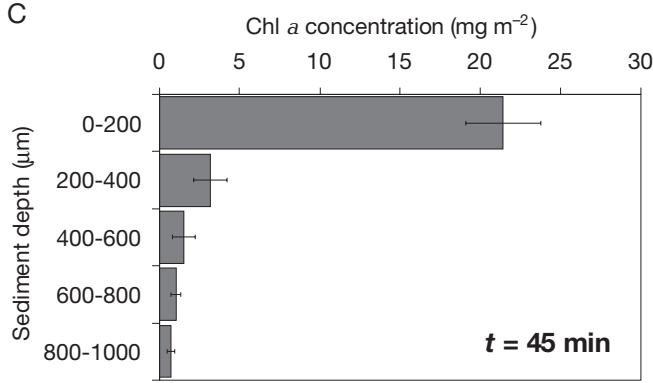

E
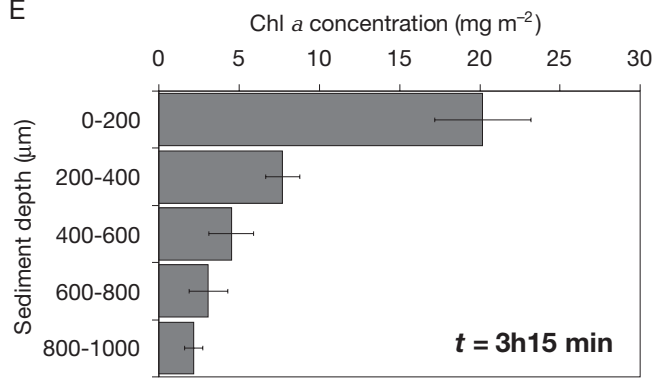

B

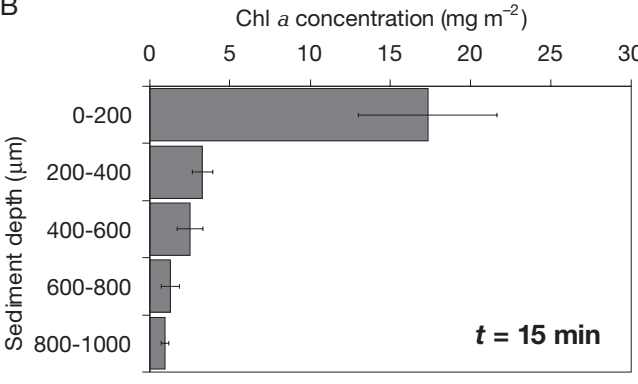

D

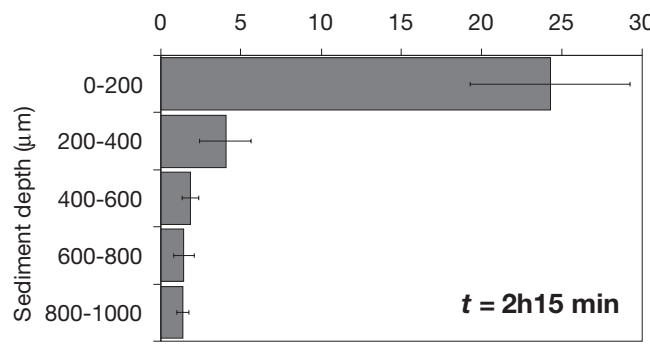

$\mathrm{F}$

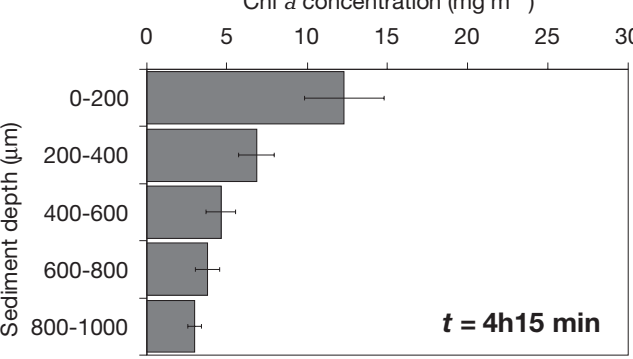

Fig. 5. Vertical profiles of biomass with $200 \mu \mathrm{m}$ resolution in the top millimetres. Horizontal bars represent chl a concentrations $(n=15)$, with confidence limits at 95\%. Profiles were established in the first millimetre of sediment at different times: (A) at the beginning of emersion ( $t=0 \mathrm{~min}$ ), (B) at $t=15 \mathrm{~min}$, (C) at $t=45 \mathrm{~min},(\mathrm{D})$ at midexposure $(t=2 \mathrm{~h} 15 \mathrm{~min})$, (E) at $t=3 \mathrm{~h} 15 \mathrm{~min}$ and (F) at the end of emersion just before the flooding tide $(t=4 \mathrm{~h} 15 \mathrm{~min})$

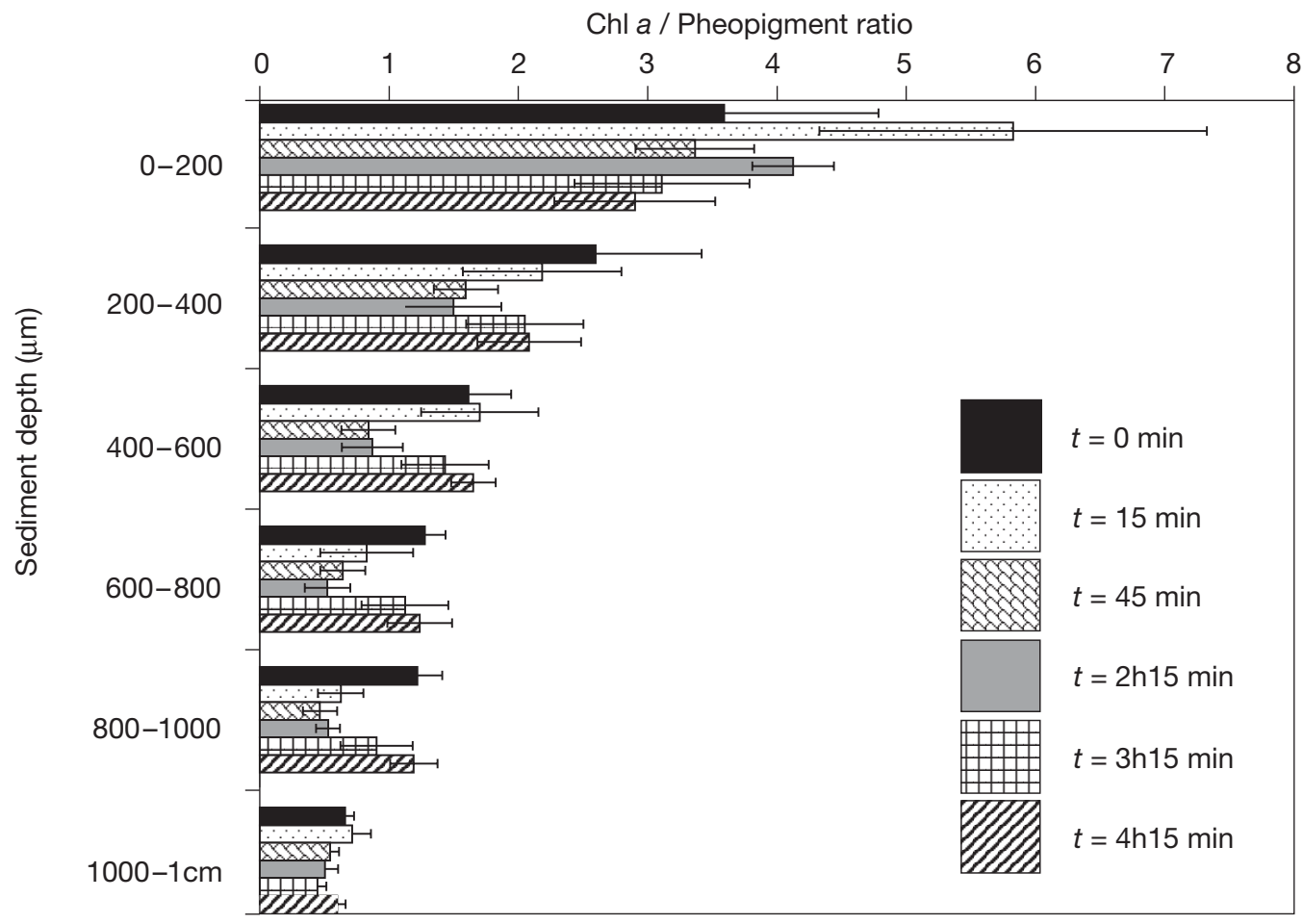

Fig. 6. Chl a to pheopigment ratio as a function of depth and time. Horizontal bars represent mean chl a/pheo ratios $(n=15)$, with confidence limits at $95 \%$. In the top $1 \mathrm{~mm}$, ratios were calculated with a $200 \mu \mathrm{m}$ resolution; then the ratio was integrated down to $1 \mathrm{~cm}$ 


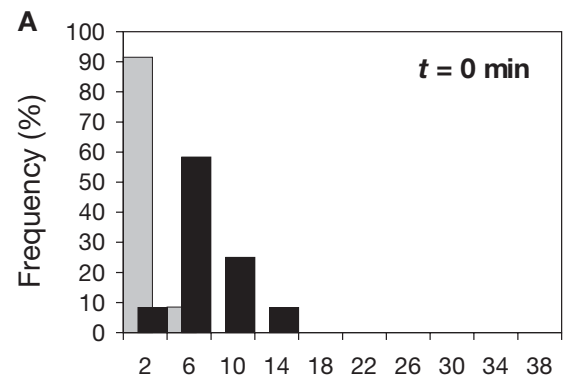

Chl a concentration classes $\left(\mathrm{mg} \mathrm{m}^{-2}\right)$
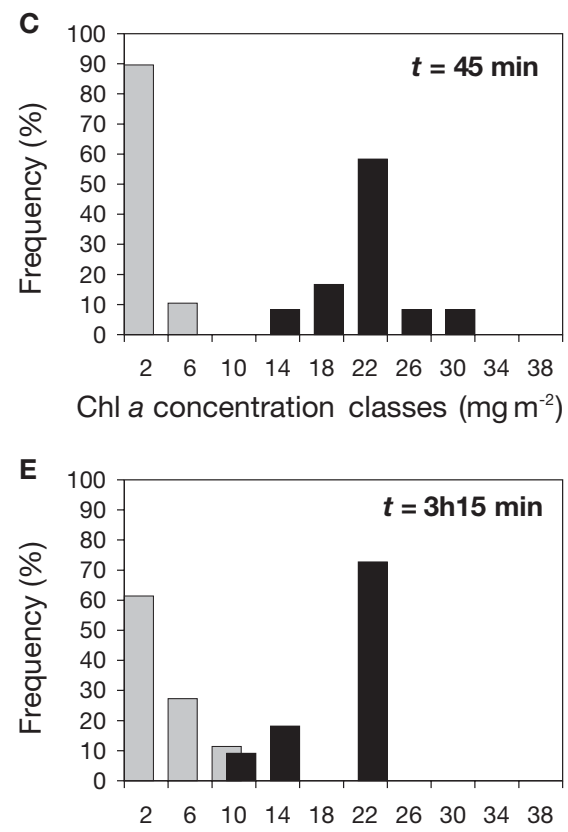

Chl a concentration classes $\left(\mathrm{mg} \mathrm{m}^{-2}\right)$

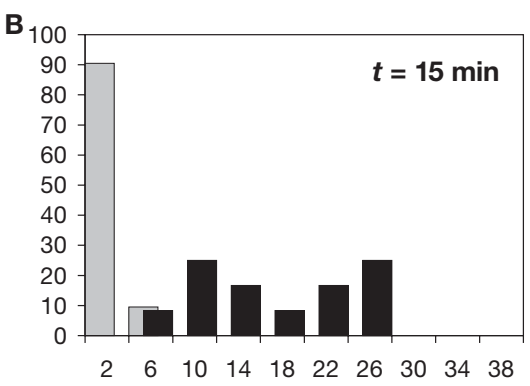

$\mathrm{Chl}$ a concentration classes $\left(\mathrm{mg} \mathrm{m}^{-2}\right)$

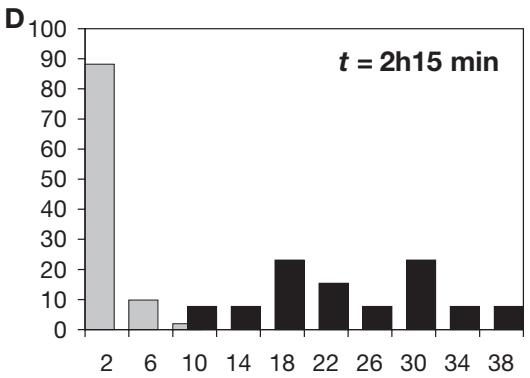

Chl a concentration classes $\left(\mathrm{mg} \mathrm{m}^{-2}\right)$

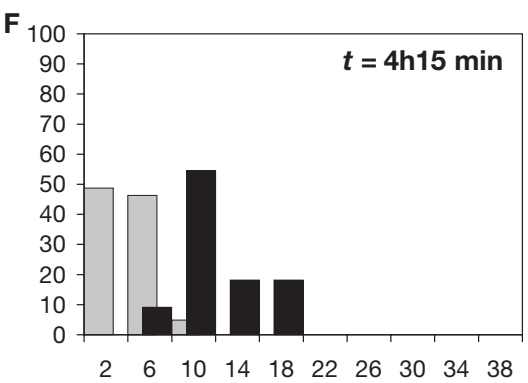

$\mathrm{Chl}$ a concentration classes $\left(\mathrm{mg} \mathrm{m}^{-2}\right)$

Fig. 7. Dynamics of biomass in the surface layer ( 0 to $200 \mu \mathrm{m})$ compared to the dynamics in deeper layers down to $1 \mathrm{~mm}$, at different emersion times: (A) beginning of emersion ( $t=0 \mathrm{~min}$ ), (B) $t=15 \mathrm{~min},(\mathrm{C}) t=45 \mathrm{~min}$, (D) mid-exposure ( $t=2 \mathrm{~h} 15 \mathrm{~min}$ ), (E) $t=3 \mathrm{~h} 15 \mathrm{~min}$ and (F) end of emersion just before the flooding tide $(t=4 \mathrm{~h} 15 \mathrm{~min}$ ). Full bars represent the frequency distribution of chl a concentrations in the surface layer (0 to $200 \mu \mathrm{m}$ ). Frequency distributions of chl a concentrations in deeper layers down to $1 \mathrm{~mm}$ with a $200 \mu \mathrm{m}$ resolution are pooled and represented by grey bars

ment (Fig. 7). This is a very important point which strongly supports the idea that the biofilm can be identified as a separate surface compartment mainly responsible for primary production, as proposed in the mathematical model of Guarini et al. (2000b). This also has important implications in terms of biomass measurement and its significance: the amount of biomass in the top $1 \mathrm{~cm}$ of the sediment usually ranges

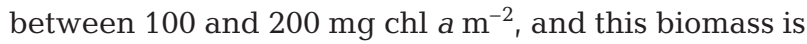
thought to be photosynthetically competent (Blanchard \& Cariou-Le Gall 1994). It becomes photosynthetically active only for the fraction that migrates to the surface of the mud to form the biofilm. As the maximum size of this biofilm is about 20 to
$25 \mathrm{mg}$ chl $a \mathrm{~m}^{-2}$, there must always be enough biomass in the top $1 \mathrm{~cm}$ to completely fill in this surface compartment or biofilm, and eventually to renew it several times. Therefore, the amount of biomass detected at the surface of the sediment during emersions - with optical methods (reflectance and $F_{0}$ ), directly (Paterson et al. 1998, Honeywill et al. 2002), or by remote sensing (Méléder et al. 2003) only refers to the biofilm and cannot be used as a predictor of the total amount of photosynthetically competent biomass. This is a very important point that must be taken into account in studies dealing with the detection of intertidal microphytobenthic biomass; otherwise, it is impossible to understand how this biomass contributes to primary production. A conceptual model about the significance of this biomass and the functioning of the primary production system on intertidal mudflats has been proposed by Guarini et al. (2000b).

Once the biofilm is well constituted (from 45 min onwards), most of the biomass was concentrated at the sediment surface ( 70 to $80 \%$ of the biomass in the top $1 \mathrm{~mm}$ was located in the upper $200 \mu m_{i}$ Fig. 5), and the cover rate tended to be less heterogeneous (Fig. 2E), but the chl a/pheo ratio, which remained rather stable at the surface, strongly decreased in the underlying layers (200 to $1000 \mu \mathrm{m}$; Fig. 6). This illustrates the fact that the most photosynthetically active cells, which were dispersed in the first $1 \mathrm{~mm}$, had migrated to the surface, thus decreasing the chl a/pheo ratio below the surface. In the second phase of emersion, when downward migration took place, an inverse process occurred, with a destratification of the biomass (Figs. 4 \& 5), a dispersion of the biofilm (Figs. 1 to 3 ) and an increase of the chl a/pheo ratio in the 200 to $1000 \mu \mathrm{m}$ layers due to the burial of photosynthetically active cells (Fig. 6). The spatio-temporal dynamics of the chl a/pheo ratio thus clearly reflects the concentration/dispersion process of the biomass in the top $1 \mathrm{~mm}$ during the succession of emersions and immersions.

Another important outcome of our observations is that the migration process, in terms of cover, can be asymmetrical: in our case study, the colonisation of the 
A

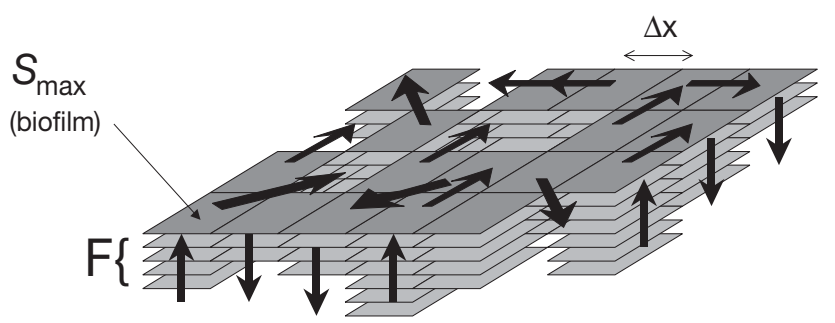

B

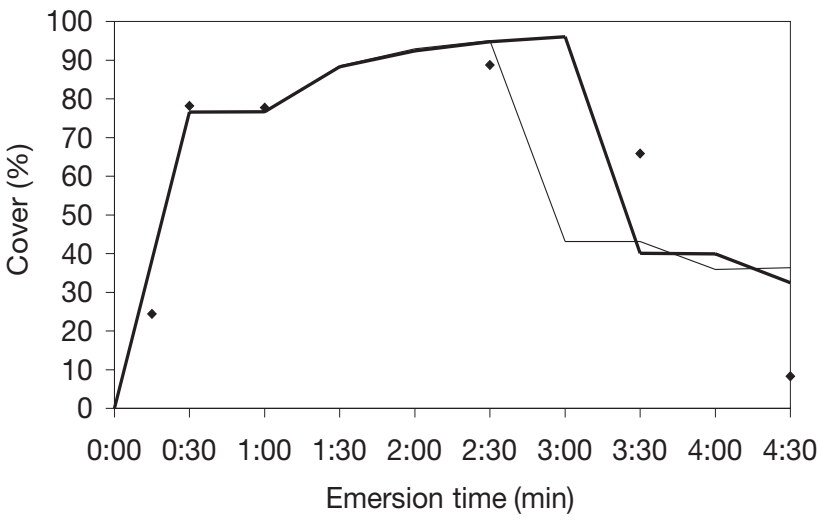

C

Emersion time $=60 \mathrm{~min}$

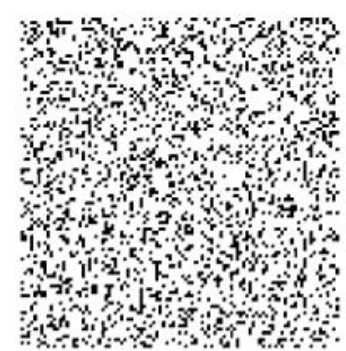

D

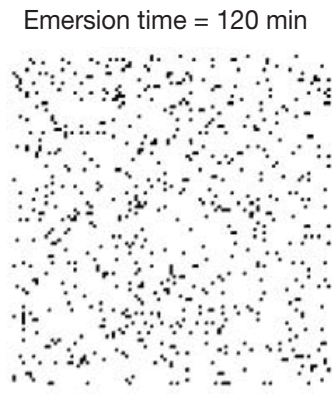

E

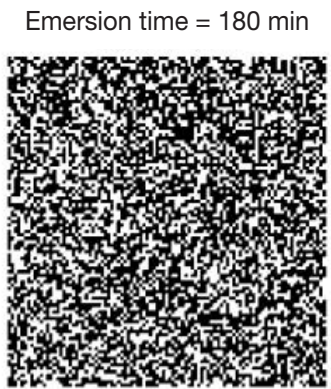

\section{$\mathrm{F}$}
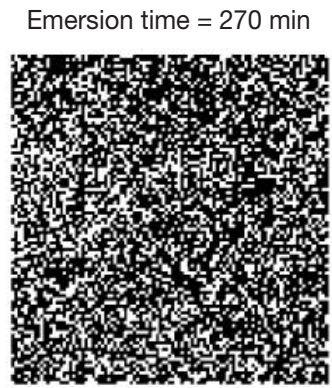

Fig. 8. Vertical migration model. (A) Schematic structure of the biofilm, as represented in the model and rules of behaviour for units of biomass: see text for details. (B) Simulations of the kinetics of cover compared to observations $(\downarrow)$ in 2 conditions: when the maximum time spent at the surface is set at $1 \mathrm{~h} 15 \mathrm{~min}(-)$ and $1 \mathrm{~h} 30 \mathrm{~min}(-)$. (C-F) Simulations of the biofilm structure at the sediment surface after emersion: black areas represent empty cells (no biomass at the surface); white areas indicate the presence of biomass surface sediment was rapid after emersion, while the burial of microalgae was slow and started almost $1 \mathrm{~h}$ in advance of the flood. This clearly points out that the biofilm can be reduced to only a small fraction of its maximum size during a large part of the emersion period (the only phase for primary production). This of course raises fundamental issues about the kinds of mechanisms that trigger the downward migration of microalgae.

\section{Modelling the spatio-temporal dynamics of the biofilm structure at the square metre scale}

The fundamental structural features that we have pointed out in the present investigation lead us to refine our representation of the microphytobenthic biofilm: (1) it covers only a fraction of the total surface area of the mudflat (even though it may be close to $100 \%$ ) and (2) the horizontal structure of the cover is a dynamic variable, as a response to the vertical migration rhythm, which can be described mathematically.

In their initial modelling approach (the only one available so far), Guarini et al. (2000a,b) described the dynamics of the microalgal biofilm with 2 sub-systems of 2 ordinary differential equations, which do not take into account these new findings:

At the beginning and during day-time emersion periods,

$$
\left\{\begin{array}{l}
\frac{\mathrm{d} S}{\mathrm{~d} t}=+r_{F} F\left(1-\frac{S}{S_{\max }}\right) \\
\frac{\mathrm{d} F}{\mathrm{~d} t}=-r_{F} F\left(1-\frac{S}{S_{\max }}\right)
\end{array}\right.
$$

where $S$ and $F$ represent the average biomass $\left(\mathrm{ML}^{-2}\right.$, where $M$ is mass and $L$ is length) in the biofilm and in the first centimetre of the mud, respectively; $r_{F}$ is the net transfer rate $\left(\mathrm{T}^{-1}\right.$, where $\mathrm{T}$ is time by vertical migration) from $F$ to $S$ and $S_{\max }$ is the average saturation value of the biomass $\left(\mathrm{ML}^{-2}\right)$. When $S_{\max }$ is reached, the mud surface is completely covered with a continuous 1 cell layer.

At the end of the day-time emersion period (before submersion or below a light threshold),

$$
\left\{\begin{array}{l}
\frac{\mathrm{d} S}{\mathrm{~d} t}=-r_{S} S \\
\frac{\mathrm{d} F}{\mathrm{~d} t}=+r_{S} S
\end{array}\right.
$$

where $r_{S}$ is the net transfer rate $\left(\mathrm{T}^{-1}\right.$, by vertical migration) from $S$ to $F$. Both rates, $r_{F}$ and $r_{S}$ are calculated on the basis of the active crawling speed of pennate diatoms (Hay et al. 1993).

To take explicitly into account the new structural and spatial characteristics of the biofilm and to simulate its 
dynamics, we propose modifying and spatialising this model. The vertical dimension is still divided into a bottom compartment $(F)$ and a surface compartment ( $S$, the biofilm), but the horizontal dimension (spatial scale is $\mathrm{m}^{2}$ ) is now divided into $I \times J$ square cells (Fig. 8A). The size of the cells $(\Delta x)$ is defined by the following relationship: $\Delta x \approx v \times \Delta t$, where $v$ is the microalgal average velocity and $\Delta t$ is the time step of the model. In the bottom compartment of each cell, the biomass $\left(F_{i, j}\left\{i=1\right.\right.$ to $I_{i} j=1$ to $\left.\left.J\right\}\right)$ that participates in the constitution of the biofilm, is divided into $n$ vertical units, each of them being equal to $S_{\max }$ (i.e. maximum size of the biofilm).

Rules of behaviour for each unit of biomass can thus be defined: in each cell, units of biomass can move upwards or downwards, but the upward migration should be completed (i.e. all units must have migrated to the surface) before downward migration can occur; units of biomass (i.e. diatoms) move permanently and each of the units at the surface $S_{\max }$ in a cell $X_{i, j}$, can move to one of the adjacent cells if it is empty; in other words, horizontal movements of the biofilm units are random, and the probability that a unit is to occupy an adjacent cell is defined as the inverse of the number of adjacent cells already empty or which will be empty following a horizontal movement of the unit already in place; the maximum time spent by units of biomass in the surface compartment is smaller than the time necessary to induce photo-inhibition, and it is set to ca. $1 \mathrm{~h}$ (according to Blanchard et al. 2004). Therefore, as soon as a unit of biomass has spent this amount of time in the surface compartment, it migrates downwards to the bottom compartment if it is not already full of units.

Results show that this new formulation of the model allows close simulation of the vertical migration observed in the field, in terms of diatom cover rate at the sediment surface (Fig. 8B): the biofilm appears quickly; the maximum cover remains in the range of 80 to $90 \%$; the biofilm disappears slowly before the end of the day-time emersion period. In addition, it is also possible to visualise, at the scale of $1 \mathrm{~m}^{2}$, the spatio-temporal dynamics of the biofilm structures (Fig. 8C-F). Although such an approach is conjectural, because we have to make assumptions about the functioning of the biofilm, it provides new insight into our way of representing the microphytobenthic biofilm. Most important, it is based on explicit rules of functioning and gives a quantitative representation that can be compared to observations. Actually, the overall agreement between simulations and observations suggests that our model provides an interesting new perspective in the way we conceive the functioning of the microphytobenthic biofilm.

\section{Relationship between the biofilm and the biomass short-term dynamics}

Despite the same temporal scales involved in the biofilm dynamics, on the one hand, and the short-term dynamics of microphytobenthic biomass (Blanchard et al. 1998, 2001, 2002), on the other hand, no attempt, based on in situ measurements (and not on a theoretical basis only), has previously been made to relate these issues. In this regard, our data clearly show that biofilm dynamics is not only involved in biomass displacement, but also in biomass production during diurnal emersion. The direct role of the microphytobenthic biofilm in a biomass increase over a diurnal emersion is evidenced: microalgal biomass can increase because individual cells migrate to the surface to perform photosynthesis in the light. This work is a significant contribution to this topic, but again much remains to be done to understand how the variability of the biofilm dynamics can explain the variability in the amount of biomass change during diurnal emersions.

Acknowledgements. This study forms part of the $\mathrm{PhD}$ thesis of O. Herlory. This work was financially supported by 'Ministère de la Jeunesse, de l'Education Nationale et de la Recherche'. The authors thank V. Huet for her assistance in the measurement of chl $a$, M. Bordes and R. Boutin, for their technical support in SEM observations.

\section{LITERATURE CITED}

Blanchard GF, Cariou-Le Gall V (1994) Photosynthetic characteristics of microphytobenthos in Marennes-Oleron Bay, France: Preliminary results. J Exp Mar Biol Ecol 182:1-14

Blanchard GF, Guarini JM, Bacher C, Huet V (1998) Control of the short-term dynamics of intertidal microphytobenthos by the exondation-submersion cycle. CR Acad Sci Ser 3 Sci Vie 321:501-508

Blanchard GF, Guarini JM, Orvain F, Sauriau PG (2001) Dynamic behaviour of benthic microalgal biomass in intertidal mudflats. J Exp Mar Biol Ecol 264:85-100

Blanchard GF, Simon Bouhet B, Guarini JM (2002) Properties of the dynamics of intertidal microphytobenthic biomass. J Mar Biol Assoc UK 82:1027-1028

Blanchard GF, Guarini JM, Dang C, Richard P (2004) Characterizing and quantifying photoinhibition in intertidal microphytobenthos. J Phycol 40:692-696

De Brouwer JFC, Stal LJ (2001) Short-term dynamics in microphytobenthos distribution and associated extracellular carbohydrates in surface sediments of an intertidal mudflat. Mar Ecol Prog Ser 218:33-44

Decho AW (2000) Microbial biofilms in intertidal systems: an overview. Cont Shelf Res 20:1257-1273

Defew EC, Paterson DM, Hagerthey SE (2002) The use of natural microphytobenthic assemblages as laboratory model systems. Mar Ecol Prog Ser 237:15-25

Edgar LA, Pickett-Heaps JD (1984) Diatom locomotion. Prog Phycol Res 3:47-88

Elliott JM (1977) Some methods for the statistical analysis of samples of benthic invertebrates, Vol 25. Freshwater Biological Association, Ambleside 
Gouleau D (1976) The role of benthic diatoms in rapid fixation of muddy Atlantic tidal flats. CR Hebd Seances Acad Sci Paris Ser D 283:21-23

Guarini JM, Gros P, Blanchard GF, Bacher C (1999) Shortterm dynamics of intertidal microphytobenthic biomass. Mathematical modelling. CR Acad Sci Ser 3 Sci Vie 322: 363-373

Guarini JM, Blanchard GF, Gros P (2000a) Quantification of the microphytobenthic primary production in European intertidal mudflats - a modelling approach. Cont Shelf Res 20:1771-1788

Guarini JM, Blanchard GF, Gros P, Gouleau D, Bacher C (2000b) Dynamic model of the short-term variability of microphytobenthic biomass on temperate intertidal mudflats. Mar Ecol Prog Ser 195:291-303

Hay SI, Maitland TC, Paterson DM (1993) The speed of diatom migration through natural and artificial substrata. Diatom Res 8:371-384

Honeywill C, Paterson DN, Hagerthey SE (2002) Determination of microphytobenthic biomass using pulse-amplitude modulated minimum fluorescence. Eur J Phycol 37: 485-492

Kelly JA, Honeywill C, Paterson DM (2001) Microscale analysis of chlorophyll-a in cohesive, intertidal sediments: the implications of microphytobenthos distribution. J Mar Biol Assoc UK 81:151-162

Kempthorne O (1955) The randomization theory of experimental inference. J Am Statist Assoc 50:946-967

Lorenzen CJ (1966) A method for the continuous measurement of in vivo chlorophyll concentration. Deep-Sea Res 13:223-227

MacIntyre HL, Geider RJ, Miller DC (1996) Microphytobenthos: the ecological role of the 'secret garden' of unvegetated, shallow-water marine habitats. 1. Distribution, abundance and primary production. Estuaries 19:186-201

Manly BFJ (1997) Randomization, bootstrap and Monte Carlo methods in biology, 2nd edn. Chapman \& Hall, London

Méléder V, Barille L, Launeau P, Carrere V, Rince Y (2003) Spectrometric constraint in analysis of benthic diatom biomass using monospecific cultures. Remote Sens Environ 88:386-400

Orvain F, Galois R, Barnard C, Sylvestre A, Blanchard G, Sauriau PG (2003) Carbohydrate production in relation to microphytobenthic biofilm. Microb Ecol 45:237-251

Palmer JD, Round FE (1967) Persistent, vertical-migration rhythms in benthic microflora. VI. The tidal and diurnal nature of the rhythm in the diatom Hantzschia virgata. Biol Bull (Woods Hole) 132:44-55

Paterson DM (1986) The migratory behaviour of diatom assemblages in a laboratory tidal micro-ecosystem exam-

Editorial responsibility: Otto Kinne (Editor),

Oldendorf/Luhe, Germany ined by low temperature scanning electron microscopy. Diatom Res 1:227-239

Paterson DM (1989) Short-term in the erodibility of intertidal cohesive sediments related to the migratory behavior of epipelic diatoms. Limnol Oceanogr 34:223-234

Paterson DM (1995) Biogenic structure of early sediment fabric visualized by low-temperature scanning electron microscopy. J Geol Soc Lond 152:131-140

Paterson DM, Crawford RM, Little C (1986) The structure of benthic diatom assemblages: a preliminary account of the use and evaluation of low-temperature scanning electron microscopy. J Exp Mar Biol Ecol 95:279-289

Paterson DM, Wiltshire KH, Miles A, Blackburn J, Davidson I, Yates MG, McGrorty S, Eastwood JA (1998) Microbiological mediation of spectral reflectance from intertidal cohesive sediments. Limnol Oceanogr 43:1207-1221

Paterson DM, Tolhurst TJ, Kelly JA, Honeywill C and 6 others (2000) Variations in sediment properties, Skeffling mudflat, Humber Estuary, UK. Cont Shelf Res 20:1373-1396

Perkins RG, Underwood GJC, Brotas V, Snow GC, Jesus B, Ribeiro L (2001) Responses of microphytobenthos to light: primary production and carbohydrate allocation over an emersion period. Mar Ecol Prog Ser 223:101-112

Round FE (1971) Benthic marine diatoms. Oceanogr Mar Biol Annu Rev 9:83-139

Serôdio J, Catarino F (2000) Modelling the primary productivity of intertidal microphytobenthos: time scales of variability and effects of migratory rhythms. Mar Ecol Prog Ser 192:13-30

Serôdio J, Silva JM, Catarino F (1997) Nondestructive tracing of migratory rhythms of intertidal benthic microalgae using in vivo chlorophyll a fluorescence. J Phycol 33: $542-553$

Smith DJ, Underwood GJC (1998) Exopolymer production by intertidal epipelic diatoms. Limnol Oceanogr 43: 1578-1591

Smith DJ, Underwood GJC (2000) The production of extracellular carbohydrates by estuarine benthic diatoms: the effects of growth phase and light and dark treatment. J Phycol 36:321-333

Underwood GJC, Kromkamp J (1999) Primary production by phytoplankton and microphytobenthos in estuaries. Adv Ecol Res 29:93-153

Underwood GJC, Paterson DM (1993) Seasonal changes in diatom biomass, sediment stability and biogenic stabilization in the Severn Estuary. J Mar Biol Assoc UK 73:871-887

Yallop ML, Paterson DM, Wellsbury P (2000) Interrelationships between rates of microbial production, exopolymer production, microbial biomass, and sediment stability in biofilms of intertidal sediments. Microb Ecol 39:116-127

Submitted: March 2, 2004; Accepted: July 29, 2004

Proofs received from author(s): October 15, 2004 